\title{
Reading Tradition in Food: An Interdisciplinary Study of Bengali Food Writing
}

\author{
Nilanjana Debnath \\ Assistant Professor of English, Koneru Lakshmaiah Education Foundation. \\ Email: njd.nilanjana1@gmail.com
}

\begin{abstract}
Food Studies has been a prominent part of Interdisciplinary Studies in the West from the 1980s and it is catching up in India as well. A close study of recipes and other forms of food writing can offer insights into the everyday culinary negotiations and the constitution of a cultural 'tradition' of taste. These insights of gastropolitics may help us better understand the functioning of subliminal hegemonic technologies and everyday resistance to the same. In our era of postcolonial globalization, where domination and subjugation happen through micro-politics of power, our readings of food writing may open new doors of reading and theorizing heritage and history.
\end{abstract}

Keywords: Food writing, recipes, cookbooks, Bengal, tradition, everyday, embodiment, taste.

\section{Introduction}

Interdisciplinarism in academic courses and research is one of the most palpable and probably the most liberating outcomes of postcolonial Humanities. Its presence is felt in the increasing numbers of departments of Interdisciplinary Humanities and postgraduation courses like Urban Studies, Ecofeminism, Posthumanism, Digital Humanities, that are being offered in colleges and universities worldwide. One such interdisciplinary field of study in humanities is food studies. Food studies, like gender studies and American studies, emerged from the tradition of Area Studies which pioneered in gathering "academics with diverse backgrounds, tools, and training" for interdisciplinary studies (Black, 2013, p. 202). The initial stages of food studies in the 1980s was defined by American studies scholars like Warren Belasco and anthropologists like Sidney Mintz, and by the late 1990s specialised groups like feminist food studies were also developed by Barbara Haber and Arlene Avakian. Food studies scholarship in India is still an emerging area and there are ongoing efforts to develop methodologies that are suitable for and attuned to our experiences of food. Till recently, scholarly representations of Indian food culture had been limited to works of Western anthropologists who have sought to theorise Western modernity by studying food practices of non-western, 'primitive' communities. Indian Food Studies seeks to redress some of the assumptions and generalizations that such studies have perpetuated and contribute to a pluralistic discourse by reading, interpreting, and theorising food literature and practices from the land.

This Open Access article is published under a Creative Commons Attribution Non-Commercial 4.0 International License (http://creativecommons.org/licenses/by-nc/4.0/), which permits non-commercial re-use, distribution, and reproduction in any medium, provided the original work is properly cited. For citation use the DOI. For commercial re-use, please contact editor@rupkatha.com. 
It is indeed necessary to develop a socio-cultural hermeneutics of food studies that is attuned to local situations and experiences of India since the cultural understanding of food in the Indian context is quite distinct from that of the West. In classical Western philosophy from Plato to Descartes, eating and thinking would constitute opposites where the former concerns solely the body and the latter the mind. However, in the classical Indian Upanishadic tradition of knowledge eating is seen as the unbroken chain of being and the ultimate truth. The Chhandogya Upanishad (VI-vi-1,2 and 3) tells us that like the best part of churned curd which rises upwards and becomes butter, in the same manner the best part of the food eaten, and water drunk rises upwards and becomes mind and prana respectively. The latter kind of approach comes close to the modern discourses of human subjectivity that understand the self as an embodied existence. Reading food as an embodied experience makes cookbooks and recipes culturally significant documents for studying the values, thoughts, and relationships of a community. Food writing such as recipes represent the intimate connection between eating and cultural norms of a community that constitutes its gastropolitics of identity. In my paper, I will attempt a brief study of the development of Bengali food writings to understand their significance as tools of cultural thought and expression which facilitate the repetition of everyday culinary and gastronomic practices. In the process of representing as well as generating everyday repetition of culinary practices, such writings constitute traditions of a gastronomic Bengaliness.

Cookbook as a form of writing is generally understood as a transcript of the performance of cooking. However, the putative practicalities of recipes in cookbooks are often questionable. For instance, Bipradas Mukhopadhyay's recipe for chhanar kalia asks the chef to be attentive for a 'gur gur' noise signalling the completion of cooking-an onomatopoeia which is neither a technical culinary term nor denotes a universally accepted sound for boiling. Variables such as the nature of utensils, temperature of cooking medium, and time make it difficult for guidelines to be precise. Cookbooks are thus much more than mere instruction manuals meant to teach cooking. As Arjun Appadurai (1988) says, "[t]he existence of cookbooks presupposes not only some degree of literacy, but often an effort on the part of some variety of specialist to standardize the regime of the kitchen, to transmit culinary lore, and to publicize particular traditions guiding the journey of food from marketplace to kitchen to table" (p. 3). In this light, cookbooks can be understood as propagating the structure that shapes the 'cultural performance' of cooking and eating in a community. Following a recipe becomes a ritualistic performance of repetition and thereby embodiment of norms that have been established as meaningful within that society.

\section{Tradition of Taste:}

The socio-cultural subjectivation of the self happens through the embodied act of reiterating communal preferences of taste. In Distinction, Bourdieu (1984) recognizes dietary preferences as an expression of "the deepest dispositions" of the habitus (p. 190). He theorizes taste as "an incorporated principle of classification which governs all forms of incorporation, choosing and modifying everything that the body ingests and digests and assimilates, physiologically and psychologically" (1984, p.190). Taste is not an inborn quality that enables one to choose one thing over another but an 'incorporated' principle of categorisation that is acquired through corporeal practices. Body is the "most indisputable materialization of class tastes", and by following certain 
ways of treating the body like caring for it, feeding it, and maintaining it, one constitutes a class identity (1984, p. 190). Gastronomic preferences develop from existing conditions of social locations and in turn are embodied through repetitive practices of culinary norms. Cookbooks aid this process of ritualization by naturalising food taboos of a community through careful instructions - prescribing distinct spices for desserts and savoury dishes or regulating the use of dairy in vegetarian and non-vegetarian recipes. This "process of formalization and ritualization, characterised by reference to the past, if only by imposing repetition" is what Hobsbawm (2003) calls an "invention of tradition" (p. 4).

\section{The $19^{\text {th }}$ Century Bengali Cookboook and Negotiations with European Tastes}

Culinary traditions work through deliberate inclusions and exclusions of recipes to constitute a certain social, economic, and cultural 'class'. Ritualised repetition of a gastronomic past, which is at once both personal as well as collective, makes meaning within a binary frame of the self and the other. This trend is very clearly visible in the earliest Bengali cookbooks written in late $19^{\text {th }}$ century when writings on food were gradually expanding from medical and mythological contexts and were stepping into the modern context of middle-class domesticity. Calcutta being the capital of the then British Indian empire, received some first-hand benefits from Western education and technology. The contact between the Western modern format of recipe and the Bengali middleclass desire to express the changing dietary styles led to the development of Bengali cookbooks. Bipradas Mukhopadhyay's Pak Pranali originally published in 1889 and Mishtanno Pak published in 1904 not only present a range of Bengali recipes from dalna to ghonto, but also include recipes for Irish stew, Swiss cake, and scalloped eggs. Mukhopadhyay prefaces his recipe for scalloped eggs by informing his readers that this is a much-loved British recipe and concludes by inviting them to prepare and taste it to judge for themselves.

These cookbooks represent the Bengali bhadralok identity of the time which entailed a knowledge of European culinary norms alongside everyday Bengali cooking. Bipradas Mukhopadhyay and his contemporaries like Bhubanchandra Basak, Debendranath Mukhopadyay, and Prajnasundari Debi were constituting the modern Bengali bhadra samaj of the growing city of Calcutta against the unsophisticated, uncivil or abhadra culture of the suburbs. At the time, the term abhadra loosely referred to people from the rural areas outside of Calcutta, who did not have access to college education or English language. In contrast, the bhadralok was born to a prosperous family in Calcutta, studied in Hindu College or other central Calcutta colleges, and cultivated literary tastes of Shakespeare and Walter Scott (Chakravartty, 2018, p. 258). The inclusion of European recipes and cooking methods effectively shapes the middle-class bhadra tastes of food and by extension tastes in Western literature and music which defined the progressiveness and modernity of the city of Calcutta.

This new style of cookbook was befitting the immediate and larger changes that colonial Bengali society was undergoing at the time. The list of ingredients with their weights, and the simple language of the instructions for cooking were especially helpful to the upcoming middleclasses in British Presidencies. The transparency of the nature and amount of ingredients would allow the middle-class housekeeper to prepare respectable meals without the possibility of wastage, which meant crucial savings in pre-refrigerator days. The emergence of cosmopolitanism 
is evident in the way cookbooks like Pak Pranali used the new format to present traditional Hindu Bengali dishes alongside Mughal and European ones. Moreover, these cookbooks were essential for shaping the image of the bhadramahila, who as part of the burgeoning discourse of Bengali modernity had to display a reinvention of domesticity. The ideal modern homemaker or grihini was one "who was skilled in the new ways of cooking as well as the old" (Sengupta, 2010, p. 94). The domestic kitchen was a key aspect in the woman question of nationalism, and the bhadramahila was tasked with the great responsibility of balancing between old, Bengali modes of culinary performance as well as appropriate European recipes as a mark of counteracting the effects of colonial domination in the public sphere. This became the new culinary 'tradition' that the colonial woman of the late nineteenth century was burdened with.

\section{The $20^{\text {th }}$ Century Cookbooks and Scientific Negotiations}

A different kind of othering happened around the mid- $20^{\text {th }}$ century when scientific discourses of food became popular owing to the late colonial introduction of home science in the curriculum of schools and colleges. Texts like Pashupati Bhattacharya's Ahar O Aharjyo and Jogendra Moitra's Probeshika Grihostho Bigyan, both first published in 1942, open with comparisons of the human body to a machine. Moitra writes that just as an engine of needs water, coal and fire, the human body too needs food and water and Bhattacharya compares the body to motorgari or car which needs indhan or fuel to function. One can see the direct influence of Descartes, who in $A$ Discourse on the Method writes, "for they will consider this body as a machine which, having been made by the hand of God, is incomparably better ordered and has in itself more amazing movements than any that can be created by men" $(2001$, p. 45). They prioritised listing nutritional values of food items over recipes. This harked back to the Cartesian dualism of Western science and food became a mere material need for the corporeal body and the rational Bengali man was shaped against the unscientific Other. In the Preface of Ahar O Aharjyo, Sri Pashupati Bhattacharya writes that the study and practice of science is of the foremost importance to rid knowledge of moho (ignorance) and to sharpen it. He laments how it is impossible to advance towards freedom while being burdened down by widespread stupidity.

Around this time, various urban women's organizations like the Women's India Association endorsed the introduction of Home Science as a practical grammar for women to improve the everyday life of the nation with scientific knowledge of hygiene, nutrition, and childcare. Such nationalist women's advocacy of Home Science "recognized domesticity as a laboratory for "indigenizing" modernity by transforming the regimens of daily life" and proposed the academic spread of the subject as a feminist project (Hancock, 2018, p. 61). Bengal and Madras were the two British Presidencies which most ardently espoused efforts for the spread of Home Science and reflected their sustained interests in social reform and nationalism.

Major changes in practices of cooking and eating took place all throughout the colonial rule in Bengal, and cookbooks silently documented all such changes. The partition of Bengal, national independence, formation of Bangladesh, all left their imprint in the changing tastes of food and cookbooks. One such instance is the recipe for bitters. Nalte pata or jute leaves were popularly used to prepare shukto, a bitter dish that was eaten at the starting of a typical Bengali lunch. In Pak Pranali, Mukhopadhyay lists the recipe for nalter shuktani and writes that like other 
5 | Reading Tradition in Food: An Interdisciplinary Study of Bengali Food Writing

types of shuktani this too must be cooked with pumpkin, mustard, and cumin paste (58). But this leaf has become rare in West Bengali cuisine owing to the partition of Bengal. The separation of East Pakistan from Bengal moved the jute fields to the other side of the border and Bengal not only suffered losses in its jute industry but also lost a long prevalent taste. Hence in cookbooks written in the latter half of the $20^{\text {th }}$ century, nalte pata or paat pata is conspicuously absent. In Purnima Thakur's Thakurbarir Ranna (1986) and Lila Majumder's Rannar Boi (1979) bitter recipes are very few, and the ones that are there make use of uchhe or kororla (bitter gourd) instead of the leaf which was eponymous for shukto. Similarly, the use of other ingredients like mustard oil, sesame seeds, and various vegetables changed over time in Bengali recipes, charting the shift from colonial to independent India and to modern West Bengal.

The turn of the 21st century witnessed a sharp rise in the volume and variety of gastronomic narratives. A considerable portion of modern food writings work within the discourse of "ethnic" cuisine. Penguin India published a cookbook series in the millennial years comprising The Calcutta Cookbook, The Essential Andhra Cookbook, The Essential Goa Cookbook, etc. The very titles indicate the essentialist assumption propagated by such narratives - of the possibility of finding a unified regional identity that is represented by their recipes. Oftentimes there are anecdotal entries before the actual recipes that strengthen regional appropriations. The Calcutta Cookbook (1995) includes short notes at the beginning of most recipes situating them in a spatiotemporal history of Bengal. A recipe for bhaja moong daler khichuri is preceded by a story about Job Charnock being offered this simple one-pot-meal on his landing at Sutanati. Or the recipe for khosha charchari (a stir-fry of vegetable peels) which follows an anecdote about a vegetable seller, Madhab Sahoo, who sold cauliflowers with their leaves on for the benefit of his customers. Such ethno-symbolic links lend these cookbooks a unique method of integrating a regional past into a cohesive narrative of identity. Some cookbooks also provide a stylized re-presentation of old recipes, like Satarupa Banerjee's Bangla Ranna (2006) where she renames the popular daab chingri as jamai bhog and calls it a "culinary marvel" (p. 14). The aestheticization is complemented by fictional and non-fictional literature on food produced in the last two decades. Within these narratives, cookbooks become bearers of an inimitable tradition that has been lost but is retrievable.

\section{$21^{\text {st }}$ Century Memoirs, Novels, and Cookbooks of Personalized Tastes}

The aesthetic stylization of recipes is also a defining feature of $21^{\text {st }}$ century food writings like food memoirs. Food memoirs or foodoirs that have gained popularity in the last two decade, combines the narrative style of life writing with a stylized cook-book style documentation of recipes. In the current times, food has exploded in the cultural scene in an unprecedented manner and a significant change has happened in the way we record our interactions with food. Even though the degree to which individual food memoirs incorporate recipes varies, the included ones are closely connected to the life experiences described by the author in the narrative part of the texts. Chitrita Banerji's memoir The Hour of The Goddess (2001) uses recipes as cornerstones in her diasporic narration and a comparison of her use of a recipe its older forms will illumine the stark contrast. For instance, Banerji locates recipes of luchi, alur dum and chholar dal amidst reminiscences of their overwhelming taste and fragrance, 
"I am overcome by the aroma of hot, puffy luchis (deep-fried puffed bread), of alur dam (slow-cooked spicy potatoes) nestling in a glistening, dark, tamarind sauce, of golden chholar dal (yellow split peas) spiced with cumin, coriander, cinnamon, and cardamom, its thick texture flecked with tiny coconut chips fried in sizzling mustard oil." (p. 4)

The adjective laden description transforms the staid instructional format of the recipe into an artistic narrative device for establishing one's Bengaliness that is at the same time communal as well as intensely personal.

Establishing one's ethnicity through the performance of traditional gastronomic rituals is an important trope in diasporic literature. Jhumpa Lahiri's The Namesake (2003) begins with Ashima attempting to recreate the remembered taste of jhalmuri in her American kitchen. She mixes Rice Krispies, Planters peanuts, and other ingredients except the mustard oil. The markets accessible to her did not sell mustard oil, which is still banned for sconsumption in USA, that would bring her approximation of jhalmuri closer to the ones she remembers from Calcutta. The mundaneness of jhalmuri in the fabric of Bengali life is underscored by the fact that it does not merit a place in any Bengali recipe book that I have come across. However, the American culinary structure had shorn it of its familiarity thus making it a unique tradition for Ashima. Thus, the simple act of bringing together this spicy mixture becomes her performance of remembering home. Lahiri's entire novel thematises this attempt to reconstitute a Bengali traditional identity in an American setting and the crisis arising from failing to do so. Like the food memoir, diasporic novels like The Namesake highlight the inward turn of food writing in the $21^{\text {st }}$ century. Experiences of food and their expression on paper has become an intimate exercise of ruminating about the self, something that is far removed from the $19^{\text {th }}$ century style of food writing in the form of cookbooks that were aimed at wider readership.

One must look at the recent surge in personalised mnemonic food narratives in the light of socio-cultural transformations that have taken place in the last two decades. On the surface, the fierce localised championing of traditions in texts like The Hour of the Goddess and The Namesake may seem like a communal feud that is being played out in these texts. However, the real Other against which these narratives strive to build their 'traditional' identities is the globalised urban sphere. Globalisation has undoubtedly disturbed domestic eating practices and reversed the system of care to the extent that "ethnic dining has become an institution and a billion-dollar enterprise." (Nandy, 2002, p. 249). While we stack our refrigerators at home with whole-wheat bread, sausages, pasta, and pizza, we dress up to go out for a bangali bhuribhoj of luchi, kosha mangsho and mishit doi. Every year Calcutta witnesses the opening of new restaurants like 6 Ballygunge Place, Saptapadi, and Bhojohori Manna that compete to serve their customers authentic Bengali cuisine. On its official page, the Peerless Inn restaurant Aheli states that they have "brought back the old lost "Zamindari cuisine", the cuisine of "Thakurbari" to the presentday Bengalis who are nostalgic of the past". The standardization of tastes robs recipes of their minor variations that is the marker of domestic creativity.

The constitution of a tradition through discourses of past 'ethnic' tastes strives to resist the homogenizing tendencies of the globalised economy that we live in. A recurring argument made in the Preface of new cookbooks is the need to remember simple home cooking (shabeki khabar) in an age of rapidly changing food habits. In the preface to her book Bangla Ranna (2006) 
Satarupa Banerjee laments the modern practice of hiring catering services for Bengali weddings. She is pained to find "ice cream has replaced sweet yoghurt". Namita Bhattacharya in Shilatty Ranna (2003) observes how preferences have shifted towards Mughlai, Chinese or Italian among her daughters' generation and how they may never know what treasures the humble Bengali cuisine may hold. Afterall, the Bengali mangsher puli is much like momos and khola pitha resembles idlis. In the preface of her cookbook Ila Ghosh declares that even though her readers may not like the methods she uses, she had to introduce them in her recipes as these are fast dying out.

\section{Conclusion:}

A tradition of taste is realised in the reiteration of food practices-past, real or imaginary-and with the desire to locate a cultural 'home' that one can claim to have roots in. However, in this effort to establish a cultural tradition one may sometimes misrepresent the past. A fitting instance of the fickleness of our cultural traditions of taste is an old tv advertisement for Dhara mustard oil. In it, a non-Bengali couple looking to purchase a new house are brought into an old Bengali one. The louvered windows, pendulum wall clock, an old piano and rosewood furniture ethnosymbolically indicate the identity of its previous owners. They come across a painting of Rabindranath Tagore which the wife is unable to recognize. In the meantime, an old Bengali couple annoyed at the Hindi conversations of their possible neighbours decide to start cooking begun bhaja in mustard oil. The pungent fumes soon waft out and the sting drives the other couple away from the premise. It ends with the company promising more pungency in its mustard oils and implying a connection between Bengaliness and the oil. The juxtaposition of Tagore and mustard oil as the two pillars of Bengali tradition is an ironic proposition as mustard oil was never a part of culinary rituals in the bhadralok circle. Women of the Tagore family such as Prajnasundari Debi's and Purnima Thakur almost always prescribe ghee as the preferred medium for their recipes. In feudal Bengal, Mustard oil was "considered fit only for the poor". (Banerji, 2007, p. 23)

This instance demonstrates how factual accuracy of a tradition is secondary to its unifying function. A tradition of taste is shaped by contingent, deliberate, communal, and personal efforts that may or may not align with singular kind of truth. However, it is not to say that traditions of taste are meaningless but that a study of the development of food writing must be undertaken in an interdisciplinary fashion, being mindful of the various historical, cultural, social, economic, linguistic aspects that leave their mark in our gastronomic transactions. The popular perception of culinary traditions as an unchanging, monolithic practice that has its origin in an unspecified time in the past must be replaced with a more nuanced understanding of traditions as a collection of inherently heterogenous practices that have collected traces of cultures it encountered as it developed. Power runs through the body politic, and the ever-changing hegemonic strategies of the state gives rise to innumerable tactics that manoeuvre these changes by repeating 'traditional' recipes. Food writing in this sense represents the everyday negotiations that a community has endured in order to sustain a sense of cultural coherence, a 'tradition', despite obvious diversification and variation in its practice of taste. It is not the moments of grand revolutions or war that these texts record, but the multitudes of quotidian micro-tactics that people adopt to resist hegemonic forces. Food studies thus becomes a significant part of the global 
interdisciplinary humanities, providing as it does a much-needed insight into the politics of everyday consumption using critical tools from various disciplines. Research on Indian food writing as representations of cultural knowledge provides the opportunity to widen the scope of humanities scholarship and move ahead from canonical, Euro-centric notions of identity and society.

\section{References:}

Appadurai, A. (1988). How to Make a National Cuisine: Cookbooks in Contemporary India. Comparative Studies in Society and History, 30(1), 3-24. http://www.jstor.org/stable/179020

Banerjee, Satarupa. (2006). Bangla Ranna: An Introduction to Bengali Cuisine. Kolkata: Orient Blackswan.

Banerji, Chitrita. (2001). The Hour of The Goddess: Memories of Women, Food and Ritual in Bengal. Penguin Books.

Banerji, Chitrita. (2007). Bengali Cooking: Seasons and Festivals ( ${ }^{\text {nd }}$ ed.). Serif Publishing.

Bhattacharya, Namita. (2003). Shilatty Ranna. Kolkata: Granthatirtha.

Bhattacharya, Pashupati. (1945). Ahar O Aharjyo (2 ${ }^{\text {nd }}$ ed.). Kolkata: Biswabharati, Kolkata.

Black, Rachel. (2013). Food Studies Programs. In Ken Albala (Ed.), Routledge International Handbook of Food Studies. USA: Routledge. $201-208$

Bourdieu, Pierre. (1984). Distinction: A Social Critique of the Judgement of Taste (Richard Nice, Trans.). Harvard University Press.

Butler, Judith. (1988). Performative Acts and Gender Constitution: An Essay in Phenomenology and Feminist Theory. Theatre Journal, (vol. 40, no. 4), 519-531.

Chakravartty, Aryendra. (2018). Understanding India: Bhadralok, Modernity and Colonial India. Indian Historical Review 45(2), 257-285. DOI: 10.1177/0376983617747999

Das Gupta, Minakshie, Gupta, Bunny, \& Chaliha, Jaya (Eds.). (1995). The Calcutta Cookbook: A Treasury of Recipes from Pavement to Palace. Penguin Books.

Debi, Prajnasundari. (2000). Amish o Niramish Ahar (vols 1 \& 2). Kolkata: Ananda Publishers.

Descartes, René. (2001). Discourse on Method, Optics, Geometry, and Meteorology (Paul J. Olscamp, Trans.). Cambridge: Hackett Publishing Company.

Douglas, Mary. (2003). The World of Goods: Towards an Anthropology of Consumption. London: Routledge.

Ghosh Ila. (2013). Ilar Hneshel e Purono Diner Ranna. Kolkata: Dey's Publishing.

Hancock, Mary. (2018). Womanhood In the Making: Domestic Ritual And Public Culture In Urban South India. New York: Routledge.

Hobsbawm, Eric. (2003). Introduction: Inventing Traditions. In Eric Hobsbawm and Terence Ranger (Eds.), The Invention of Tradition. Cambridge University Press.

Lahiri, Jhumpa. (2003). The Namesake. Harper Collins Publishers.

Majumder, Lila \& Chattopadhyay, Kamala. (2014). Rannar Boi (4 ${ }^{\text {th }}$ ed.). Kolkata: Ananda Publishers. 
9 | Reading Tradition in Food: An Interdisciplinary Study of Bengali Food Writing

Moitra, Jogendranath. (1942). Probeshika Garhostho Bigyan O Shwasthobidhi (3 ${ }^{\text {rd }}$ ed.). Kolkata: The Book Company Limited.

Mukhopadhyay, Bipradas. (1907). Pak Pranali (5 $5^{\text {th }}$ ed.). Kolkata: Gurudas Chattopadhyay and Sons.

Nandy, A. (2002). Ethnic Cuisine: The significant 'other'. India International Centre Quarterly, 29(3/4), 246251. http://www.jstor.org/stable/23005830

Sengupta, J. (2010). Nation on a Platter: The Culture and Politics of Food and Cuisine in Colonial Bengal. Modern Asian Studies, 44(1), 81-98. http://www.jstor.org/stable/27764647

Thakur, Purnima. (2014). Thakurbarir Ranna (10 ${ }^{\text {th }}$ ed.). Kolkata: Ananda Publishers.

Dr. Nilanjana Debnath is a researcher in the area of Food Studies in India. Her interest in interdisciplinary literary research was cultivated during her undergraduate years in Presidency College and postgraduation in Calcutta University, and culminated in a $\mathrm{PhD}$ on food memoirs from the Department of English Literature, English and Foreign Languages University, Hyderabad. She has presented papers in national and international conferences, and published papers on various aspects of literary gastropolitics. Currently, she teaches English to undergraduate students as an Assistant Professor in the Department of Humanities and Sciences, KL University Hyderabad. 